\title{
CHARATERISTICS OF GYNECOLOGICAL ABNORMALITIES AND TYPES OF URINE DIVERSION AT DR SOETOMO HOSPITAL, SURABAYA, INDONESIA, IN THREE-YEAR PERIOD
}

\author{
Soetojo, Ambo Tuwo Nurdin \\ Department of Urology, Faculty of Medicine, Universitas Airlangga, Dr Soetomo Hospital, Surabaya, Indonesia
}

\section{ABSTRACT}

\begin{abstract}
In the case of advanced stage gynecological disorders, most patients have a disturbance in the upper urinary tract. Most patients with uterine cervical carcinoma are already in stage $3 B$ and require urine diversion. The purpose of this study is to find and determine the profile of gynecological disorders that require urine diversion, the type of urine diversion, and urine diverted output in patients with cervical carcinoma. This descriptive analytical retrospective study was conducted at Dr. Soetomo Hospital, Surabaya, Indonesia, between 2012 and 2015. The samples of this study were all patients with gynecological disorders who underwent retrograde DJ stent procedures, underwent ureterocutaneostomy and nephrostomy at the Integrated Central Surgery Building, Dr. Soetomo Hospital, Surabaya, for three years between 2012 and 2015. Data was collected based on the medical record number of patients with gynecological disorders who underwent urine diversion procedures and were recorded in the book on the operation schedule. We find that the most common cause of gynecological abnormalities in kidney obstruction is cervical carcinoma. There are three types of urine diversions used, namely DJ stent, percutaneous nefropyelostomy, and ureterocutaneostomy, with DJ as the most commonly performed. Urine diversion can improve creatinine without being influenced by the type of diversity.
\end{abstract}

Keywords: Gynecological abnormalities; urine diversion; DJ stent; nephropyelostomy; ureterocutaneostomy

\section{ABSTRAK}

Pada kasus kelainan ginekologis dengan stadium lanjut, sebagian besar pasien sudah mengalami gangguan pada traktus urinarius bagian atas. Hampir sebagian besar penderita karsinoma cervix uterus sudah berada dalam stadium $3 B$ dan memerlukan diversi urine. Tujuan penelitian ini adalah untuk mencari dan menentukan profil kelainan ginekologis yang memerlukan diversi urine, jenis diversi urine, dan output diversi urine pada penderita karsinoma serviks. Penelitian retrospektif deskriptif analitik ini dilakukan di Dr. Soetomo Hospital, Surabaya, Indonesia, antara tahun 2012 sampai 2015. Sampel penelitian ini adalah semua pasien dengan kelainan ginekologis yang menjalani prosedur pemasangan DJ stent secara retrograde, menjalani ureterokutaneostomi dan nefrostomi di Gedung Bedah Pusat Terpadu, Dr. Soetomo Hospital, Surabaya, selama tiga tahun antara tahun 2012 dan 2015. Data dikumpulkan berdasarkan nomor rekam medis pasien dengan kelainan ginekologis yang menjalani prosedur diversi urine dan tercatat pada buku jadwal operasi. Kami mendapatkan bahwa penyebab terbanyak kelainan ginekologi penyebab obstruksi ginjal adalah karsinoma serviks. Terdapat tiga macam diversi urine yang digunakan yaitu DJ stent, nefropyelostomi perkutan, dan ureterokutaneostomi, dengan DJ sebagai yang tersering dilakukan. Diversi urine dapat memperbaiki kreatinin tanpa dipengaruhi jenis diversinya.

Kata kunci: Kelainan ginekologis; diversi urin; DJ stent; nefropyelostomi; ureterokutaneostomi

Correspondence: Soetojo, Department of Urology, Faculty of Medicine, Dr Soetomo Hospital, Jalan Prof dr Moestopo 6-8, Surabaya 60286. Email: s.tojowirjopranoto@yahoo.com

pISSN:2355-8393 • eISSN: 2599-056x • doi: http://dx.doi.org/10.20473/fmi.v55i2.14347

- Fol Med Indones. 2019;55:133-138 • Received 12 Nov $2018 \bullet$ Accepted 23 May 2019

- Open access under CC-BY-NC-SA license • Available at https://e-journal.unair.ac.id/FMI/

\section{INTRODUCTION}

Pathotological abnormalities of the female reproductive organs in advanced conditions have an effect on the urinary tract, especially the upper urinary tract. Variations in pathological abnormalities in the female reproductive organs cause mild to severe effects based on their anatomical location, such as cervical carcinoma, ovarian tumors and others. Uterine cervical carcinoma is the most malignancy suffered by women in Indonesia (Kanou et al 2007).

Data in 2010 at Dr. Soetomo Hospital Surabaya showed that there were 3638 new cases diagnosed as uterine cervical carcinoma (Dr. Soetomo Hospital 2010), but there were no valid data regarding other gynecological 
abnormalities, such as ovarian tumors, ovarian cysts, and others. Most patients with gynecologic abnormalities come with advanced stages and have caused upper urinary tract disorders. More than 40 percent of patients with uterine cervical carcinoma are in stage $3 \mathrm{~B}$ and require urine diversion (Singh et al 2012).

Hydronephrosis in gynecologic disorders can be caused by direct tumor invasion of the ureter, impingement by a tumor mass, retroperitoneal metastatic, or enlarged lymph nodes (Aziz 2009). Hydronephrosis and bilateral ureteral dilatation due to impaired urine flow over a long period of time will be accompanied by renal parenchymal damage, causing obstructive nephropathy which can be irreversible (Sundar et al 2008). Urine diversion is needed to prevent deteriorating kidney function. Urinary diversion in gynecological disorders, such as cervical carcinoma and ovarian cancer, is needed in the condition of ureteric obstruction, both unilateral and bilateral, urosepsis, uremia and hyperkalemia, persistent renal colic, and worsening the degree of hydronephrosis and kidney function characterized by increased serum creatinine and decreased Glomerular Filtration Rate (GFR) (Russo 2000).

Urine diversion can be done by retrograde double $\mathrm{J}$ (DJ stent) catheter, ureterocutaneostomy and percutaneous nephrostomy. The three choices can be made alone or in combination between the two to optimize the diversion of urine in accordance with the severity and severity of complications caused. Kouba and colleagues stated that the failure rate of DJ stent in cases of extrinsic ureteric thrombosis due to malignancy is quite high, especially if accompanied by persistent hydronephrosis and low back pain, ranging from $16 \%-58 \%$ (Kouba et al 2008). Failure of DJ stents in ureteric obstruction due to malignancy is also quite high in ureteral distal distal obstruction when compared to proximal or renal pelvic level obstruction (Kouba et al 2008). Gumilar et al stated that there was no relationship between the gradation of hydronephrosis and the success rate of retrograde DJ stent placement in patients with uterine cervical carcinoma (Gumilar et al 2012).

This study intends to find and determine the profile of gynecological abnormalities that require urine diversion, the type of urine diversion, and urine diverted output in patients with uterine cervical carcinoma, SOT and ovarian cysts in Dr. Soetomo Hospital. By knowing the profile of gynecological disorders that require diversion of urine and the type of urine diversion and urine diverted output, the important role, benefits and types of urine diversion will be understood. In the end, the accuracy of the choice of type and time to do urine diversion can improve the quality of life of patients with advanced gynecological disorders, especially in cases of cervical carcinoma.

The purpose of this study is to determine the profile of patients with gynecological disorders who need urine diversion, to know the type of urine diversion based on gynecological disorders, to know the benefits of urine diversion in advanced gynecological disorders, and to know the benefits of selecting urine diversion based on gynecological disorders.

\section{MATERIALS AND METHODS}

This research was conducted at the Dr. Soetomo Hospital, Surabaya, Indonesia, in the period 2012 to 2015. This study was a descriptive analytical retrospective study. The sample of this study was all patients with gynecological disorders who underwent retrograde stent DJ procedures, uretero-cutaneostomy and nephrostomy at the Central Operating Theater, Dr. Soetomo Hospital, Surabaya, for three years between 2012 and 2015.

Data were collected based on the medical record number of patients with gynecological disorders that were recorded in the book schedule of surgery for Central Surgery who underwent a urine diversion procedure. Next, we search the data variables needed through the status of patients in the Medical Record Installation, Dr. Soetomo, Surabaya.

The dependent variable in this study is the type of urine diversion, and the independent variables in this study are the pathological diagnosis of gynecological abnormalities, types of gynecological abnormalities, degree of hydronephrosis, and preoperative serum creatinine levels. The research data obtained were analyzed descriptively and analytically. The results of the analysis are presented narratively in table form.

\section{RESULTS AND DISCUSSION}

Gynecological disorders are one of the many diseases that are very common and are highly associated with urological disorders. Data collected in the Department of Urology, Dr. Soetomo Hospital, showed that the cases were managed at the central operating theater for 3 years as many as 124 cases.

\section{Distribution of diseases and complications}

Data collected from Dr. Soetomo Hospital from January 2012 to December 2014 showed that the most cases were cervical cancer by $105 \%(84.7 \%)$ and the least cases were ovarian cysts in 4 patients $(3.2 \%)$. All 
patients averaged $49.19 \pm 10.06$ years. The data can be seen in Table 1.

Table 1. Distribution of diseases

\begin{tabular}{lcc}
\hline Diseases & $\mathrm{n}$ & Percentages $(\%)$ \\
\hline Cervical cancer & 105 & 84.7 \\
SOT & 15 & 12.1 \\
Ovarian cysts & 4 & 3.2 \\
\hline Total & 124 & 100 \\
\hline
\end{tabular}

Table 2. Distribution of age (years)

\begin{tabular}{ccccc}
\hline & $\mathrm{N}$ & Minimum & Maximum & Mean \pm SD \\
\hline Age & 124 & 17 & 77 & $49.19 \pm 10.06$ \\
\hline
\end{tabular}

The data also show gynecological abnormalities accompanied by hydronephrosis. Data from the Urology Department shows that in the cases handled at the Central Operating Theater, the most abnormalities were cervical carcinoma with bilateral hydronephrosis in 105 patients $(84.7 \%)$, the second was SOT with bilateral hydronephrosis of 10 patients $(8.1 \%)$ and those with the least were ovarian cysts with bilateral hydronephrosis in 1 patient $(0.8 \%)$ (Table 3$)$.

\section{Types of procedures in the field of gynecology and urology}

Gynecological abnormalities obtained were divided into 2, namely operable and not operable. From operable cases, Total Abdominal Hysterectomy (TAH) was performed in 15 patients, Unilateral SalpingoOophorectomy (USO) in 11 patients, and cystectomy in 3 patients. Cases that cannot be operated on are 95 cases. This can be seen in Table 4 .

All urology cases at the Central Operating Theater, Dr. Soetomo Hospital, for 3 years were divided into two, namely the case with the successful diversion of urine and cases without the success of urine diversion. Urine diversification was divided into three, namely DJ stent 106 cases, unilateral hydronephrosis (HN) 8 cases (7.5\%) and bilateral HN 98 cases $(92.5 \%)$, percutaneous nephropyelostomy (PNS) 6 cases, bilateral HN 6 cases $(100 \%)$ and ureterocutaneousostomy (UCS) 11 cases, while failure in 1 patient. The average age of patients with PNS treatment is $49.00 \pm 5.10$, UCS $51.18 \pm 5.94$ and DJ stents $49.98 \pm 10.65$. All of this data can be seen in Table 5.

\section{SK level of the patient after urine diversion}

Patients who successfully underwent diversion showed improvement in kidney function (Table 7).

Data shows that there are three gynecological abnormalities, namely cervical cancer, SOT and ovarian cysts that cause complications in the field of uurology. Ureteral obstruction that occurs slowly and over a long period of time, as in the case of obstructive uropathy due to uterine cervical carcinoma, causes changes in kidney tissue that is often asymptomatic until deterioration of kidney function is truly real. The most cases were cervical cancer $105 \%(84.7 \%)$ and the least were ovarian cysts in 4 patients $(3.2 \%)$. All patients averaged $49.19 \pm 10.06$ years. The clinical condition of patients is characterized by uremia, impaired fluid and electrolyte balance, urinary tract infections, decreased consciousness, and leads to death (Olivera et al 2010). The second most case was SOT with bilateral hydronephrosis of 10 patients $(8.1 \%)$ and the least was ovarian cysts with bilateral hydronephrosis 1 patient $(0.8 \%)$. If ureteric obstruction is not removed, the death of tubular cells and nephrons occurs within 15 days (Russo 2000).

In the dog model that underwent unilateral complete ureteral ligation for 7 days, the GFR value of 1 hour after obstruction removal reached $25 \%$ of the GFR value before ligation. Maximum recovery reaches $58 \%$ of baseline GFR and it occurs 57 days after removal of ureteric obstruction. Improvement of GFR after removal of ureteric obstruction reduced only to $70 \%$ after 14 days, $30 \%$ after 4 weeks, and there was absolutely no improvement in renal function despite ureteric desobstruction after unilateral ureteric obstruction lasted for 6 weeks (Marszalek et al 2009). Therefore, the procedure of ureteral desobstruction with any cause needs to be done immediately to prevent deteriorating renal function that is irreversible.

Table 3. Distribution of diseases based on diagnosis

\begin{tabular}{lcc}
\hline Diagnosis & Frequency $(\mathrm{n})$ & Percentages $(\%)$ \\
\hline Cervical cancer + Bilateral hyrdronephrosis & 105 & 84.7 \\
SOT + Unilateral hyrdronephrosis & 5 & 4.0 \\
SOT + Bilateral hyrdronephrosis & 10 & 8.1 \\
Ovarian cysts + Unilateral hyrdronephrosis & 3 & 2.4 \\
Kista Ovarium + Bilateral hyrdronephrosis & 1 & 0.8 \\
\hline Total & 124 & 100 \\
\hline
\end{tabular}


Table 4. Distribution of obstetric and gynecological procedures to the type of hydronephrosis

\begin{tabular}{lcccccc}
\hline \multirow{2}{*}{ Procedure } & \multicolumn{3}{c}{ Hydroneprhosis } & \multicolumn{2}{c}{ Total } \\
\cline { 2 - 5 } & $\begin{array}{c}\text { Unilateral } \\
\text { hyrdronephrosis }\end{array}$ & $\%$ & $\begin{array}{c}\text { Bilateral } \\
\text { hyrdronephrosis }\end{array}$ & $\%$ & $\mathrm{n}$ & $\%$ \\
\hline TAH & 4 & 26.7 & 11 & 73.3 & 15 & 100 \\
USO & 0 & 0 & 11 & 100 & 11 & 100 \\
Cystectomy & 2 & 66.7 & 1 & 33.3 & 3 & 100 \\
None & 2 & 2.1 & 93 & 97.9 & 95 & 100 \\
\hline Total & 8 & 6.5 & 116 & 93.5 & 124 & 100 \\
\hline
\end{tabular}

Table 5. Distribution of urological procedures to the type of hydronephrosis

\begin{tabular}{lcccccc}
\hline \multirow{2}{*}{ Procedures } & \multicolumn{2}{c}{ Hydroneprhosis } & \multicolumn{2}{c}{ Total } \\
\cline { 2 - 5 } & $\begin{array}{c}\text { Unilateral } \\
\text { hyrdronephrosis }\end{array}$ & $\%$ & $\begin{array}{c}\text { Bilateral } \\
\text { hyrdronephrosis }\end{array}$ & $\%$ & $\mathrm{~N}$ & $\%$ \\
\hline DJ Stent & 8 & 7.5 & 98 & 92.5 & 106 & 100 \\
PNS & 0 & 0 & 6 & 100 & 6 & 100 \\
UCS & 0 & 0 & 11 & 100 & 11 & 100 \\
Failed & 0 & 0 & 1 & 100 & 1 & 100 \\
Total & 8 & 6.5 & 116 & 93.5 & 124 & 100 \\
\hline
\end{tabular}

Table 6. Age distribution for various urine diversion procedures (data presented in the mean \pm SD form)

\begin{tabular}{lc}
\hline Procedures & Ages \\
\hline DJ Stent & $49.98 \pm 10.65$ \\
PNS & $49.00 \pm 5.10$ \\
UCS & $51.18 \pm 5.94$ \\
\hline
\end{tabular}

Table 7. The serum creatinine values of pre and post various acts of urine diversion (data are presented in the mean $\pm \mathrm{SD}$ form)

\begin{tabular}{llc}
\hline Procedures & Pre DJ Stent & Post DJ Stent \\
\hline DJ Stent & $2.11 \pm 1.11$ & $1.34 \pm 1.07$ \\
PNS & $5.87 \pm 2.78$ & $1.47 \pm 1.97$ \\
UCS & $8.00 \pm 2.86$ & $1.62 \pm 0.37$ \\
\hline
\end{tabular}

Some researchers report different figures regarding the success in urine diversion. Urine diversification was divided into three, namely DJ stent 106 cases (unilateral HN 8 cases $(7.5 \%)$ and bilateral HN 98 cases $(92.5 \%)$, PNS 6 cases (bilateral HN 6 cases $(100 \%)$, and ureterocutaneostomy 11 cases, whereas cases that failed occurred in 1 patient. The average age of patients with PNS was $49.00 \pm 5.10$, UCS $51.18 \pm 5.94$ and DJ stents $49.98 \pm 10.65$. Yossepowitch et al (2001) explained that the cause of ureteric (extrinsic or intrinsic) obstruction, level, and degree of hydronephrosis was associated with successful retrograde DJ stent placement. The retrograde rate of DJ stent failure was $77 \%$ in patients with extrinsic ureteral obstruction, while in patients with ureteric obstruction intrinsic by $23 \%$.

Preoperative serum creatinine levels and certain urologists as operators have no effect on the success of retrograde DJ stent placement (Danilovic et al 2005). Danilovic et al (2005) explained that the failure rate of DJ stents was $52 \%$ in extrinsic ureteral obstruction and 9\% in intrinsic ureteral obstruction. The ureteral estuary was not identified when cystoscopy plays a role in $77 \%$ of the failure of DJ stent installation in malignant ureteral obstruction (MUO) (Hewitson 2009). Whereas, Gumilar et al (2012) stated that there was no 
relationship between the gradation of hydronephrosis and the success rate of retrograde DJ stent placement in patients with uterine cervical carcinoma.

Based on the results obtained, this study illustrates that cervical carcinoma stage and the degree of hydronephrosis are associated with the success of DJ stent placement in the ipsilateral kidney with hydronephrosis, with a significant level of significance $(p=0.05)$. The higher the degree of hydronephrosis, the higher the likelihood of failure of the DJ stent on the ipsilateral side of the kidney hydronephrosis. Conversely, if the kidney is still non-obstructive or with mild obstruction (mild hydronephrosis), the success of DJ stent installation in patients with uterine cervical carcinoma is still quite high.

Statistical analysis was carried out without considering the side of the kidney experiencing hydronephrosis. It is clear that the degree of hydronephrosis is consistently associated with the success of retrograde DJ stent placement in patients with uterine cervical carcinoma with a significant level of significance $(p=0.002)$. On the other hand, the stage of uterine cervical carcinoma, the time span between the pathological diagnosis of uterine cervical carcinoma and the time of DJ stent placement, and preoperative serum creatinine levels were not significantly associated with successful retrograde DJ stent placement in patients with uterine cervical carcinoma.

\section{CONCLUSION}

The most common causes of gynecological disorders that cause kidney obstruction, both bilaterally and unilaterally, are cervical carcinoma. There are 3 types of urine diversification, namely DJ stent, percutaneous nephropyelostomy (PNS) and ureterocutaneostomy (UCS), and the most commonly done is DJ stent. The urine diversification carried out can improve creatinine without being influenced by the type of diversity.

\section{REFERENCES}

Aziz MF (2009). Gynecological cancer in Indonesia. Journal Gynecol Onco 20, 8-10

Danilovic A, Antonopoulus IM, Mesquita JL (2005). Likelihood of retrograde double-J stenting according to ureteral obstructing pathology. International Braz J Urol 31, 431-36

Gumilar OB, Soebadi DM, Tarmono, Askandar B, Pudjirahardjo WJ (2012). Oral phenazopyridine $\mathrm{HCl}$ for ureter orifice identification and retrograde stenting. Unpublished

Hewitson TD (2009). Renal tubulointersitial fibrosis: common but never simple. Am J Physiol Renal Physiol 296, 1239-44

Kanou T, Fujiyama C, Nishimura K, Tokuda Y, Uozumi J, Masaki Z (2007). Management of extrinsic malignant ureteral obstruction with urinary diversion. International Journal of Urology 14, 689-92

Kouba E, Wallen EM, Pruthi RS (2008). Management of ureteral obstruction due to advanced malignancy : Optimizing therapeutic and palliative outcomes. The Journal of Urology 180, 444-50.

Olivera ST, Gjulsen S, Katica Z (2010). Obstructive nephropathy as a result of malignant neoplasms: A single centre experience. BANTAO Journal 8, 71-74

RSUD Dr Soetomo (2010). Data pasien kanker mulut rahim Poli Ginekologi Onkologi RSUD Dr. Soetomo Surabaya

Russo P (2000). Urological emergency in the cancer patient. Seminars in Oncology 27, 284

Singh I, Strandhoy JW, Assimos DG (2012). Patophysiology of urinary tract obstruction. In: Campbell-Walsh Urology. 10th ed. Philadelphia, Elsevier Saunders, p 1087-121

Sundar S, Horne A, Kehoe S (2008). Cervical cancer. BMJ Clinical Evidence 3, 818

Yossepowitch O, Lifshitz DA, Dekel Y, Gross M, Keidar DM, Neuman M, et al (2001). Predicting the success of retrograde stenting for managing ureteral obstruction. J Urol 166, 1746-9 